\title{
FADS1 genetic variant rs174547 as a molecular-genetic biomarker for CVD risk - a study from Bulgaria
}

\author{
Elena Kuzova, Tzveta Georgieva, \\ Vesselka Duleva \\ National Center of Public Health and Analyses, \\ "Acad. Ivan Evst. Geshov", Sofia 1431, Bulgaria \\ Corresponding author: \\ Elena Kuzova \\ "Acad. Ivan Evst. Geshov", 1431 Sofia, Bulgaria \\ Phone: +359883497351 \\ Fax: +35928056361 \\ E-mail address: e.kuzova@ncpha.government.bg
}

\begin{abstract}
The input of molecular genetic biomarkers allows individual assessment of metabolic pathways and the behaviour of the major enzymes responsible for nutrient conversion. This in turn enriches the nutrigenetic information fund, and the panels of well-studied gene variants and their interaction with nutrients can be used to create precise personalized diets. Our objective was to determine the significance of the rs 174547 genetic variant in the fatty acid desaturase 1 (FADS1) gene in the metabolism of saturated and unsaturated fatty acids ingested with food and to identify the potential of FADS1 rs 174547 as a molecular genetic marker to be included in a panel of nutrigenetic studies in order to prepare a personalized diet plan. A total of 123 volunteers (43 men and 80 women) from Bulgaria, aged 28 to 65 years, were tested for rs 174547 in the FADS1 gene. A DNA sample was taken from each volunteer by a non-invasive method (buccal swabs), and the genetic variant of each individual was determined by molecular genetic approaches. Their general health was assessed by taking anthropometric and body impedance measurements data and completing a lifestyle survey. The lipid profile included testing for triglycerides, total cholesterol, HDL and LDL cholesterol, and blood sugar. Information on the total food intake was collected through questionnaire methods. The results of the statistical tests show that there is a statistically significant difference between the two genotypes only in HDL cholesterol levels $(P=0.044$, at $P<0.05)$ - carriers of the $C / T$ genotype have lower mean concentration values of $\mathrm{HDL}$-cholesterol $(1.27 \mathrm{mmol} / \mathrm{l})$ than for $T / T$ variant carriers (1.48 $\mathrm{mmol} / \mathrm{I})$. Among men, there were statistically significant differences in mean levels of total cholesterol $(P=0.012)$ and HDL cholesterol $(P=0.008)$ between the two genotypes. Among women, there was a statistically significant difference between the two genotypes only in terms of mean triglyceride levels $(P=0.007)$. The differences in the other studied indicators do not satisfy the criterion for significance $(P<0.05)$. The results suggest an effect of the intake of SFA (saturated fatty acids) and MUFA (monounsaturated fatty acids) on the relationship between rs 174547 polymorphism and plasma lipids (total and LDL-cholesterol) only in men. Studies of the Bulgarian population prove extremely low intake of omega-3 fatty acids due to low consumption of fish. These findings and the lack of data for Bulgaria on genetic variants of FADS1 are a prerequisite for conducting in-depth studies of both risk groups, such as patients with cardiovascular disease, dyslipidaemia or nutritional deficiency of LC-PUFAs, and in healthy people.
\end{abstract}

Key words: genetic variants; FADS1 genes; metabolism of fatty acids; molecular-genetic biomarkers; personalized nutrition. 


\section{INTRODUCTION}

About 500 single nucleotide polymorphisms (SNPs) affecting the FADS1 and FADS2 (Fatty Acid Desaturases) genes have been identified, and there is growing scientific evidence that these gene variants must be taken into account when determining the nutritional requirements for polyunsaturated fatty acids [1]. Therefore, the same intake of linoleic acid (LA) and alphalinolenic acid (ALA) can lead to different health effects in different individuals. The differences are due to gene variations that affect the corresponding metabolism and the activity of enzymes associated with it.

The composition of polyunsaturated fatty acids (PUFAs) in human tissues is of great importance for health and depends on both food intake and endogenous metabolism of the individual. The metabolism of PUFAs is controlled by a number of genes, including FADS1 and FADS2 which encode delta- 5 and delta- 6 desaturases, major enzymes involved in the metabolism of polyunsaturated fatty acids [2,3]. Desaturases are the rate-limiting enzymes for the synthesis of longchain polyunsaturated fatty acids (LC-PUFAs): arachidonic acid (AA), eicosapentaenoic acid (EPA), and docosahexaenoic acid (DHA), from their food precursors LA and ALA. AA and EPA are the ancestral fatty acids in the formation of eicosanoids, and DHA for the synthesis of docosanoids [1]. Plasma levels of long-chain polyunsaturated fatty acids are determined by both dietary and endogenous metabolism, with the conversion of PUFAs to LC-PUFA in the human body being catalyzed by elongase and desaturase activity $[1,4,5]$.

It is also known from the science of nutrigenetics that some genetic variants of the gene encoding delta-5-desaturase of fatty acids enzyme are associated with a higher incidence of coronary artery disease (CAD) and that the intake of $n-3$ polyunsaturated fatty acids modifies in a positive direction the effect of this genetic variant on the incidence of coronary artery disease. The relationship between fatty acid consumption and cardiovascular events is now well known. Many studies show that regular and high consumption of ALA, DHA and EPA obtained from fish and seafood and from oils rich in ALA have a protective effect in cardiovascular disease, dyslipidemia and sudden cardiac death $[6,7]$.

\section{OBJECTIVE}

After a molecular genetic method was developed and implemented to detect the $r s 174547$ genetic variant in the FADS1 gene [8], the importance of this polymorphism in the metabolism of saturated and unsaturated fatty acids in food had to be determined. To do this, the genotype for rs 174547of Bulgarian volunteers was determined and the influence of the specific genetic variant of the FADS1 gene on fatty acid metabolism was assessed. After statistical analyses were conducted on lipid status and genotype, the potential nutrigenetic significance and health risks were analyzed. The present study also determined the frequency and distribution of rs 174547 gene variants among the Bulgarian population. Thus, the potential of the given single nucleotide polymorphism rs 174547 as a molecular genetic marker to be included in a panel of nutrigenetic studies in order to prepare a personalized diet plan was evaluated.

\section{METHODS}

\section{Study group}

A total of 123 volunteers from the Pleven and Sofia regions, aged 28 to 65 years, were tested for their gene variant with respect to $r 5174547$ in the FADS1 gene. Of these, 43 were males (35\%) and 80 were females (65\%). Their general health was assessed by taking anthropometric data and completing a lifestyle survey. The lipid profile included testing for triglycerides, total cholesterol, HDL and LDL cholesterol, and blood sugar. Through survey methods, information was collected on the total food intake, the data were processed with a software program and energy, micro- and macronutrients and vitamins were calculated. During the study one of the volunteers was confirmed to be pregnant. Accordingly, a genetic test was performed and valid data on her general health status, diet and lifestyle were obtained, but no valid anthropometric and biochemical data were available. The connection with two other volunteers was lost and as a result they only underwent testing for genetic markers. Accordingly, their results are included in the statistical analysis for distribution of $r s 174547$ among the Bulgarian population, but the lack of other detailed information about them necessitates their exclusion from the analysis and their discussion in the main study. A DNA sample was taken from each volunteer by a non-invasive method, and the genetic variant of each individual was determined by molecular genetic approaches, fully described in our previous article [8].

\section{Methods for assessment of general health and lipid profile}

\section{Anthropometric data}

Height $(\mathrm{m})$ and weight $(\mathrm{kg})$ were measured, and body mass index (BMI) was calculated in $\mathrm{kg} / \mathrm{m}^{2}$. Height and weight were measured twice in all subjects, both values were recorded and the average value was taken if there were differences. Waist circumferences $(\mathrm{cm})$ and hips $(\mathrm{cm})$ are measured twice, taking an average value. 


\section{Body impedance measurements}

For the method of bioelectric impedance analysis was used a professional body analyzer brand "Tanita" - BCATBF-300M. The following parameters were measured: body weight in $\mathrm{kg}$, impedance (bioelectrical resistance of the body) in $\Omega$, adipose tissue (FM) in $\mathrm{kg}$, adipose tissue in \%, free fat mass (FFM) in $\mathrm{kg}$, total body water (TBW) in kg, body mass index (BMI) basic metabolism in kilojoules (kJ) and kilocalories (kcal).

\section{Clinical and biochemical studies}

For analysis and evaluation of the lipid profile, the following blood parameters were examined: triglycerides $(\mathrm{mmol} / \mathrm{L})$, total cholesterol $(\mathrm{mmol} / \mathrm{L}), \mathrm{HDL}$ cholesterol $(\mathrm{mmol} / \mathrm{L})$, LDL cholesterol $(\mathrm{mmol} / \mathrm{L})$, blood sugar $(\mathrm{mmol} / \mathrm{L})$, the reference values of which are given in Table 1. Blood pressure - twice, at 5-minute intervals, qualified systolic and diastolic blood pressure of patients in a sitting position on the right hand was measured by qualified medical staff.

Table 1. Reference values of biochemical parameters in lipid profile.

\begin{tabular}{|l|l|l|}
\hline \multirow{2}{*}{ Indicator } & \multicolumn{2}{|l|}{ Reference values, (mmol/l) } \\
\cline { 2 - 3 } & female & male \\
\hline $\begin{array}{l}\text { Blood glu- } \\
\text { cose }\end{array}$ & $\begin{array}{l}7.0 \mathrm{mmol} / \mathrm{l} \text { fasting and } 11.1 \mathrm{mmol} / \mathrm{l} \text { after glucose } \\
\text { loading or feeding ** }\end{array}$ \\
\hline Triglycerides & $0.3-1.7$ \\
\hline $\begin{array}{l}\text { Cholesterol } \\
\text { total }\end{array}$ & $3.5-5.2$ & \multicolumn{2}{|l}{} \\
\hline \multirow{4}{*}{ HDL } & Without risk $>1.68$ & Without risk $>1.45$ \\
& Moderate risk 1.15- & Moderate risk $-0.90-$ \\
& 1.68 & 1.45 \\
& High risk $<1.15$ & High risk $<0.90$ \\
\hline \multirow{3}{*}{ LDL } & Optimal levels & $<2.59$ \\
& Close to optimal & $2.59-3.36$ \\
& Borderline high & $3.37-4.13$ \\
& High & $4.14-4.89$ \\
& Extremely high & $\geq 4.90$ \\
\hline
\end{tabular}

* Reference values according to the recommendations of the European Community for atherosclerosis [10].

**Reference values according to guidelines and recommendations for laboratory analysis in the diagnosis and treatment of diabetes [11].

\section{Molecular genetic laboratory methods}

A buccal mucosa sample was collected from the inside of the cheek using a sterile swab $(15.2 \mathrm{~cm}$, individually packaged Cat. № 25-1506 1 PF 100, Progen Ltd) and placed in $200 \mu \mathrm{l}$ PBS buffer $(\mathrm{pH}$ 7.4) for further use. DNA extraction was performed using the Gene
GET Genomic DNA Purification Kit (Thermo Fisher Scientific, Cat. No: K0721) from buccal mucosa samples, according to the manufacturer's recommendations. The DNA concentration was measured spectrophotometrically (Agilent 8453 UV-Visible Spectroscopy System, Agilent Technologies) at a wavelength of $260 \mathrm{~nm}$ and $280 \mathrm{~nm}$. All samples were tested by real-time PCR, using fluorescently labelled probes for allelic discrimination. All PCR reactions were performed in a 7300 Teal Time PCR System (Applied Biosystems) according to the manufacturer's instructions. The reaction volume is $25 \mu \mathrm{l}$ and the mixture contains $12.5 \mu \mathrm{l}$ TaqMan $^{\circledR}$

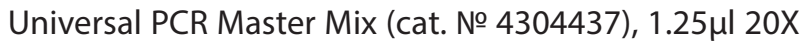
TaqMan SNP Genotyping Assay - containing a pair of primers and a fluorescently labeled probe (ThermoFisherScientific, cat. $13 \mu$ l PNase 6.2 № PNase4) / DNase Free Water (Fermentas) and $5 \mu$ ldiluted DNA sample. All reactions were performed in the presence of two negative controls: 1. RNase/DNase Free Water (Nontemplate control, NTC); 2. Bacterial DNA. DNA samples from volunteers with already proven and known genotypes obtained after the design of their own primer system and subsequent genetic sequencing [8] were used for positive controls. PCR amplification was performed using the protocol described in Table 2.

Table 2. Basic steps and corresponding conditions for conducting a real-time polymerase chain reaction to detect rs 174547 polymorphism in the FADS1 gene.

\begin{tabular}{|c|l|}
\hline Step & Conditions \\
\hline 1 & $60^{\circ} \mathrm{C}$ for $120 \mathrm{sec}$. \\
\hline 2 & $95^{\circ} \mathrm{C}$ for $600 \mathrm{sec}$ \\
\hline 3 & $95^{\circ} \mathrm{C}$ for $15 \mathrm{sec}$ \\
\hline 4 & $60^{\circ} \mathrm{C}$ for $60 \mathrm{sec}$. \\
\hline 5 & Fluorescence reading (plate read) \\
\hline 6 & $\begin{array}{l}\text { Step No. } 3,4 \text { and } 5 \text { are repeated } 44 \text { more times } \\
\text { (a total of } 45 \text { cycles for the entire protocol) }\end{array}$ \\
\hline 7 & Cooling and holding at $40^{\circ} \mathrm{C}$ (end of protocol) \\
\hline
\end{tabular}

\section{Survey Method \\ Food Frequency Questionnaire Method (FFQ)}

Frequency of food consumption was examined using a standardized Food Frequency Questionnaire (FFQ). The developed questionnaire includes foods/groups of foods ranked by frequency of consumption. Participants note the frequency with which they consume a variety of foods over a long period of time, in this case one year, in order to assess normal food intake. The number of foods varies depending on the purpose of the study. All volunteers filled in a questionnaire for the frequency of food and beverage consumption. For the purposes of the study, a modified consumption 
frequency questionnaire (FFQ) was used, used in the National Survey of Health Risk Factors in the Population Over the Age of 20, conducted in 2014. Food intake falls into one of 7 discriminatory categories: less than once a month, 1-3 times a month, once a week, 2-4 times a week, 5-6 times a week, once a day, more than once a day. For more convenient and understandable presentation of the results, in the analysis of the data, these seven categories were combined into three: 1) 3 times a month and less often - a category showing relatively low or even no intake of the food/product; 2 ) 1-4 times a week - a category showing a moderate intake of the respective food and 3) more than 5-6 times a week - a category reporting a relatively high intake of the respective food.

\section{Health status and risk factors for chronic diseases}

This questionnaire consists of several categories of questions concerning personal data, health data, eating habits, physical activity, healthy lifestyle and behaviour, fish and omega-3,6 supplementation, harmful habits such as smoking or alcohol abuse, etc.

\section{Statistical analysis methods}

The analysis of the results was done using the statistical data processing package SPSS ver.17. MS Excel 2016 was used for tabular and graphical presentation of the results.

Descriptive statistics were used to describe the data: variation (for quantitative variables) and frequency analysis (for qualitative variables), graphical representation; $X^{2}$ Test and Fisher's Test were used to compare the proportions; the Wilcoxon Test was used to compare related samples. Normality of the data distribution was statistically studied by KolmogorovSmirnov and Shapiro-Wilk tests. A T-Test was used to compare two mean values with a normal distribution. The ANOVA test was used to compare more than two means. The Mann-Whitney test to compare mean values was used in the abnormal distribution of quantitative variables.

Regression and correlation analysis were also used, and a nonparametric Spearman test was used for data with abnormal distribution.

\section{RESULTS AND DISCUSSION}

Ready-made commercial kits, which include specifically designed fluorescently labeled probes (detectors), were used to perform the given Real-Time PCR reactions. During the reaction, the detectors generate a signal, which is read in the appropriate colour (channel with filters for fluorescence detection with specific parameters). The generated signal corresponds to a multiplied (amplified) region of DNA that interests us and thus the PCR amplification curve of the corresponding unknown DNA sample is obtained (Figure 1).
A)

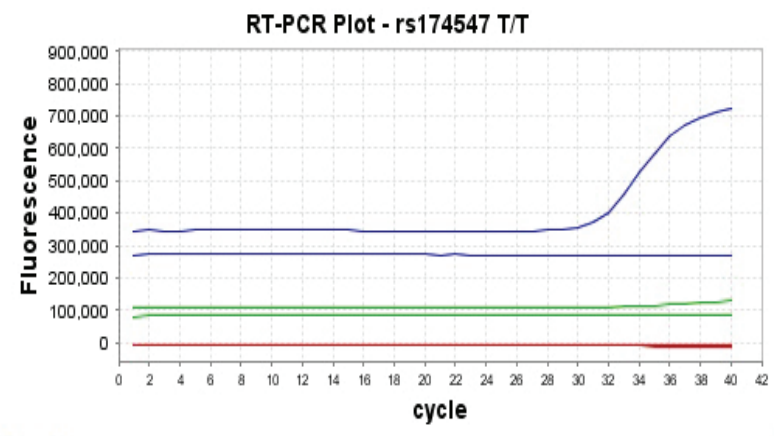

ROX $\square$ VIC $\square$ FAM

B)

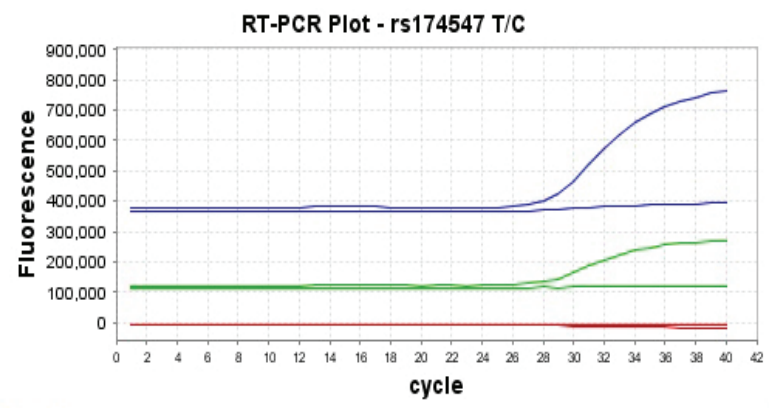

$\square$ ROX $\square$ VIC $\square$ FAM

Figure 1. Real Time PCR amplification chart. Figure 1 clearly shows a logarithmic increase of only one amplification curve (blue colour, Figure 1A) compared to the used negative control in homozygotes and a similar logarithmic increase of both curves (blue and green colour, Figure 1B) in the samples of persons with polymorphism defined as heterozygous.

\section{Determination of allelic frequency and frequency of genotypes with respect to rs 174547 SNP polymorphism in the FADS1 gene among the Bulgarian population}

Genetic variations in populations can be analyzed and quantified by allelic frequency. Two fundamental calculations are essential for population genetics: allele frequencies and genotype frequencies. For the first time, the allelic frequency and individual genotypes were determined among people from the Bulgarian population with respect to rs174547 SNP polymorphism in the FADS1 gene (Figure 2).

The data show that in the entire study group, homozygous $\mathrm{T} / \mathrm{T}$ carriers (of the same $\mathrm{T}$ allele in both copies of the gene) were defined as $49.6 \%(61 / 123)$ and heterozygous $\mathrm{C} / \mathrm{T}$ carriers ( $\mathrm{T}$ allele carriers in one copy of the gene and $C$ allele in the other copy) are the 
remaining 50.4\% (62/123). Respectively, homozygous $\mathrm{C} / \mathrm{C}$ carriers were not registered in the study group.

Relative distribution of the genotype among the population group, $n$ $=123$

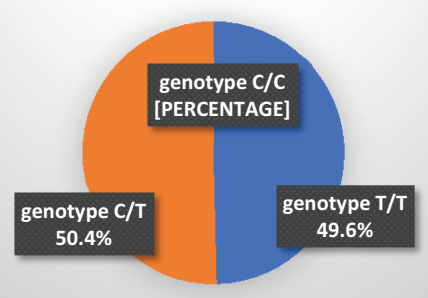

Figure 2. Percentage distribution of the rs174547 genotype among the studied population group.

The results obtained for the prevalence and frequency of the genotype between the two sexes are shown in Figure $\mathbf{3 a}$ and Figure $\mathbf{3} \mathbf{b}$. The distribution of individual genotypes by sex shows that the $\mathrm{T} / \mathrm{T}$ genotype is slightly more common among the studied women (51\%), and among men - C/T genotype (56\%) (Figure 3).

a)

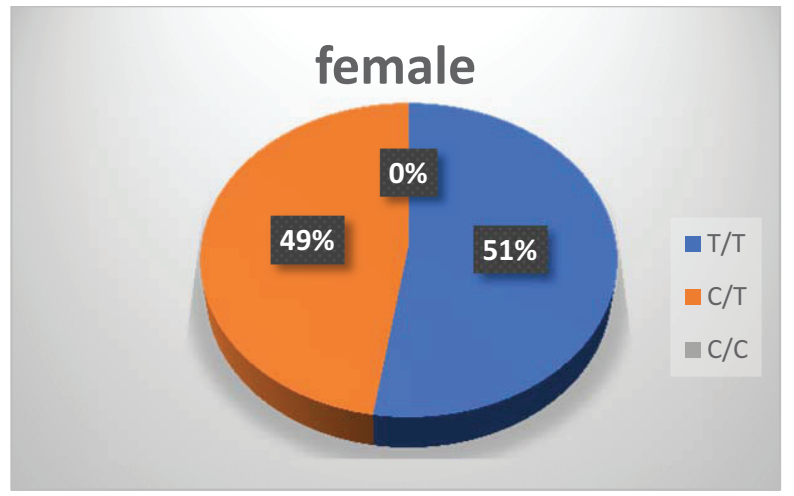

b)

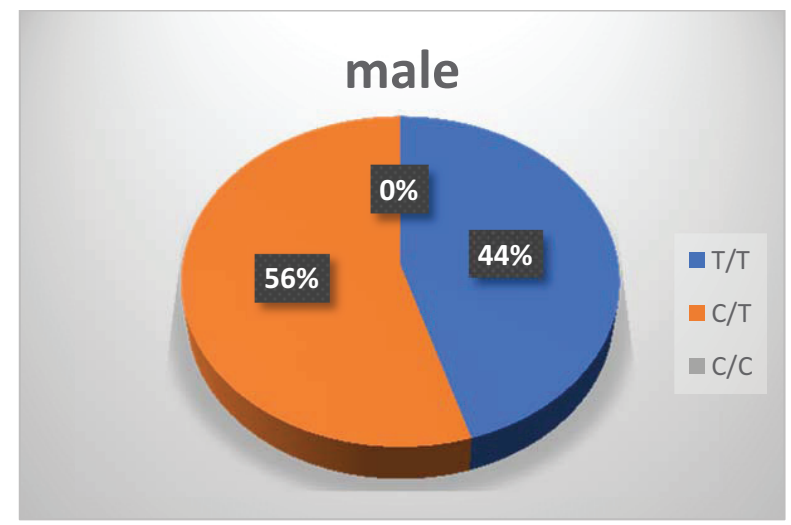

Figure 3. Distribution of the $r s 174547$ genotype among women a) and men b).

The frequency of the T allele based on the obtained data was calculated as 0.75 , analogous to a $\mathrm{T}: \mathrm{C}$ ratio of
3:1 (184:62; expressed as a percentage - 75\% : $25 \%$ in favor of the T-allele). Accordingly, the frequency of the C allele is 0.25 (62/246, 25\%) (Table 3). The obtained results are surprising, both almost equal distribution between the individual genotypes $C / T$ and $T / T$, and the lack of individuals with a certain homozygous genotype only by $C$ allele $(C / C)$. It is possible that the results obtained are a consequence of the number of individuals in the study group (limited to 123 volunteers), but in general they are in unison and reflect the lower frequency of the $C$ allele worldwide.

This allele is considered a progenitor variant, and according to the Ensembl database (www.Ensembl. org) its average frequency is calculated at MAF $=0.30$ (C), and the highest recorded population value is MAF $=0.588$. Globally, the allelic frequency is $T=0.702$ (3516), $C=0.298$ (1492), and the frequency of the respective genotype is $\mathrm{T} / \mathrm{T}=0.560$ (1401), $\mathrm{C} / \mathrm{C}=0.155$ (389) and $C / T=0.285$ (714). However, the relatively small number of subjects is noticeable, which also identifies the need for research to continue by adding more individuals from the respective population groups. Compared with data from other studies of the same polymorphism, the allele frequency of the $C$ allele is lower in Africans, African Americans, and South Asians (Table 3). It is not known that data on this particular polymorphism is available for other neighbouring Balkan countries.

The obtained results show that the T allele is more common among the Bulgarian population - 75\%, which according to Fengqiong et al. is the less favourable genetic variant of FADS1, as it is a risk factor for coronary artery disease. It is important to note that the T-allele is associated with a higher risk of CAD only among individuals with lower dietary intakes of EPA and DHA, but not in those with higher intakes of these long-chain polyunsaturated fatty acids [9].

\section{Clinical and biochemical parameters of the study participants}

The measurement of lipids and lipoproteins is used to assess the risk of atherosclerotic cardiovascular disease (ASCVD) and as a guide for therapeutic decision-making by specialists. Quantitative evaluation of plasma lipids can be performed with blood plasma, and quantification of lipoproteins is achieved by measuring their protein component. The reference limits for biochemical parameters are the limits according to the recommendations of the European Community for atherosclerosis (for the lipid profile) [10] and according to the Guidelines and recommendations for laboratory analysis in the diagnosis and treatment of diabetes (for blood glucose) [11]. Evidence of the causal effects of lipids and lipoproteins on the risk of atherosclerotic cardiovascular disease is becoming more and more systematic. 
Table 3. Allelic and genotypic frequency of FADS1 rs 174547T > C SNP in the studied Bulgarian population, compared with other populations and countries.

\begin{tabular}{|c|c|c|c|c|c|c|c|}
\hline \multirow{2}{*}{$\begin{array}{l}\text { Country / } \\
\text { population }\end{array}$} & \multirow{2}{*}{$\begin{array}{l}\text { excerpt } \\
\text { (N) }\end{array}$} & \multirow{2}{*}{$\begin{array}{l}\text { Allelic } \\
\text { frequency } \\
\text { - C allele }\end{array}$} & \multirow{2}{*}{$\begin{array}{l}\text { Allelic } \\
\text { frequency } \\
\text { - T allele }\end{array}$} & \multicolumn{3}{|c|}{ Genotype frequency } & \multirow[t]{2}{*}{ Data source } \\
\hline & & & & T/T n (\%) & C/T n (\%) & C/C n (\%) & \\
\hline Bulgaria & 123 & 0.250 & 0.750 & $61(49.60)$ & $62(50.40)$ & $0(0.00)$ & Present study \\
\hline China & 951 & 0.343 & 0.657 & $326(34.30)$ & $437(45.90)$ & $188(19.80)$ & $\begin{array}{c}\text { Data for China } \\
\text { PubMed ID: } 28359317\end{array}$ \\
\hline $\begin{array}{l}\text { North Ameri- } \\
\text { cans } \\
\text { (originating in } \\
\text { Europe) }\end{array}$ & 24 & 0.333 & 0.667 & $9(37.50)$ & $14(58.30)$ & $1(4.20)$ & $\begin{array}{c}\text { Data from dbSNP } \\
\text { PubMed: ss } 24050300\end{array}$ \\
\hline $\begin{array}{l}\text { African Ameri- } \\
\text { cans }\end{array}$ & 23 & 0.065 & 0.935 & $20(86.96)$ & $3(13.04)$ & $0(0.00)$ & $\begin{array}{l}\text { Data from dbSNP - PubMed: } \\
\text { ss } 24050300\end{array}$ \\
\hline $\begin{array}{l}\text { North Ameri- } \\
\text { cans } \\
\text { (originating in } \\
\text { China) }\end{array}$ & 24 & 0.500 & 0.500 & $8(33.33)$ & 8 (33.33) & $8(33.33)$ & $\begin{array}{l}\text { Data from dbSNP - PubMed: } \\
\text { ss } 24050300\end{array}$ \\
\hline Americans & 347 & $0.588(408)$ & 0.412 & $69(19.90)$ & $148(42.70)$ & $130(37.50)$ & $\begin{array}{c}\text { Data from Ensembl: } \\
1000 \text { Genome Project Phase } 3 \\
\text { Ref. SNP rs } 174547\end{array}$ \\
\hline Africans & 661 & $\begin{array}{l}0.023 \\
(30)\end{array}$ & 0.977 & $631(95.50)$ & $30(4.50)$ & $0(0.00)$ & $\begin{array}{c}\text { Data from Ensembl: } \\
1000 \text { Genome Project Phase } 3 \\
\text { Ref. SNP rs } 174547\end{array}$ \\
\hline East Asians & 504 & $0.566(571)$ & 0.434 & $116(23.00)$ & $205(40.70)$ & $183(36.30)$ & $\begin{array}{c}\text { Data from Ensembl: } \\
1000 \text { Genome Project Phase } 3 \\
\text { Ref. SNP rs } 174547\end{array}$ \\
\hline South Asians & 489 & $0.137(134)$ & 0.863 & $365(74.60)$ & $114(23.30)$ & $10(2.00)$ & $\begin{array}{c}\text { Dada from Ensembl: } \\
1000 \text { Genome Project Phase } 3 \\
\text { Ref. SNP rs } 174547\end{array}$ \\
\hline Europeans & 503 & $0.347(349)$ & 0.653 & $220(43.70)$ & $217(43.10)$ & $66(13.10)$ & $\begin{array}{c}\text { Data from Ensembl: } \\
1000 \text { Genome Project Phase } 3 \\
\text { Ref. SNP rs } 174547\end{array}$ \\
\hline $\begin{array}{l}\text { Average for } \\
\text { the world }\end{array}$ & 2504 & $\begin{array}{c}0.298 \\
(1492)\end{array}$ & 0.702 & $\begin{array}{c}1401 \\
(56.00)\end{array}$ & $714(28.50)$ & $389(15.50)$ & $\begin{array}{c}\text { Data from Ensembl: } \\
1000 \text { Genome Project Phase } 3 \\
\text { Ref. SNP rs } 174547\end{array}$ \\
\hline
\end{tabular}

The results of the summary data on the biochemical laboratory parameters of the volunteers from the present study are shown in Table 4. The mean value in total cholesterol levels in volunteers was $6.0 \mathrm{mmol} / \mathrm{l}$ $(\mathrm{SD}=1.2, \mathrm{Me}=5.8)$, not differing in men and women, with a reference range of $3.5-5.2 \mathrm{mmol} / \mathrm{l}$. The mean value of triglyceride levels among the study group was $1.92(\mathrm{SD}=1.20, \mathrm{Me}=1.70)$, with women TG $=1.90(\mathrm{SD}$ $=1.26, \mathrm{Me}=1.68)$ and $\mathrm{men} \mathrm{TG}=1.95(\mathrm{SD}=1.09, \mathrm{Me}=$ 1.77). TG values between $0.3-1.7 \mathrm{mmol} / \mathrm{l}$ are accepted as reference limits. As can be seen, the average value of this indicator is higher than the reference upper limit of the norm for triglycerides.
Triglyceride-rich very low-density lipoprotein (VLDL) particles and their residues carry most of the circulating triglycerides in the blood. Therefore, the plasma concentration of TG reflects the concentration of circulating ApoB-containing lipoproteins rich in TG. Elevated plasma TG levels are associated with an increased risk of ASCVD, but this association becomes zero after correction for non-HDL-c, estimating the total concentration of all ApoB-containing lipoproteins [12]. Researchers have suggested that all ApoB-containing lipoproteins have an identical effect on the risk of cardiovascular events [13]. Together, these studies strongly suggest that the causal effect of TG-rich lipoproteins and their residues on ASCVD risk is determined by the 
Kuzova et al.: FADS1 genetic variant rs 174547 as molecular-genetic biomarker for CVD risk...

Table 4. Clinical and biochemical parameters $(\mathrm{mmol} / \mathrm{l})$ of the participants by sex.

\begin{tabular}{|c|c|c|c|c|c|c|c|c|c|}
\hline $\begin{array}{c}\text { Biochemical } \\
\text { indicator }\end{array}$ & \multicolumn{3}{|c|}{ Total } & \multicolumn{3}{c|}{ Female } & \multicolumn{3}{c|}{ Male } \\
\hline & Mean & SD & Median & Mean & SD & Median & Mean & SD & Median \\
\hline \begin{tabular}{c} 
Triglycerides \\
\hline $\begin{array}{c}\text { Cholesterol } \\
\text { total }\end{array}$
\end{tabular} & 1.92 & 1.20 & 1.70 & 1.90 & 1.26 & 1.68 & 1.95 & 1.09 & 1.77 \\
\hline $\begin{array}{c}\text { HDL- } \\
\text { cholesterol }\end{array}$ & 1.45 & 0.48 & 1.34 & 1.49 & 0.48 & 1.43 & 1.37 & 0.48 & 1.29 \\
\hline $\begin{array}{c}\text { LDL- } \\
\text { cholesterol }\end{array}$ & 3.66 & 1.14 & 3.60 & 3.66 & 1.17 & 3.55 & 3.65 & 1.09 & 3.70 \\
\hline $\begin{array}{c}\text { Blood glu- } \\
\text { cose }\end{array}$ & 5.68 & 1.25 & 5.32 & 5.66 & 1.30 & 5.29 & 5.72 & 1.18 & 5.47 \\
\hline
\end{tabular}

concentration of circulating ApoB-containing particles and not by the TG content itself. In the volunteers of the present study, the mean values of low-density lipoprotein LDL-c were $3.66 \mathrm{mmol} / \mathrm{I}(\mathrm{SD}=1.14, \mathrm{Me}=3.60)$, with no significant differences between women (LDL-c $=3.66, \mathrm{SD}=1.17, \mathrm{Me}=3.55)$ and men $(\mathrm{LDL}-\mathrm{C}=3.65$, $\mathrm{SD}=1.09, \mathrm{Me}=3.70)$. According to the European Atherosclerosis Community, levels below $2.59 \mathrm{mmol} / \mathrm{l}$ are considered optimal.

The determined mean value of high-density lipoproteins (HDL-Chol) in the subjects studied in this study was $1.45 \mathrm{mmol} / \mathrm{l}(\mathrm{SD}=0.48, \mathrm{Me}=1.34)$. There are slight differences between the mean values of men HDL-c $=1.37 \mathrm{mmol} / \mathrm{I}(\mathrm{SD}=0.48, \mathrm{Me}=1.29)$ and women $\mathrm{HDL}-\mathrm{c}=1.49$ (SD = 0.48, $\mathrm{Me}=1.43)$. According to the European Atherosclerosis Community, women with $\mathrm{HDL}$ over $1.68 \mathrm{mmol} / \mathrm{l}$ and men with $\mathrm{HDL}$ over $1.45 \mathrm{mmol} / \mathrm{l}$ are at no increased risk.

The mean fasting blood glucose level in participants was $5.68 \mathrm{mmol} / \mathrm{l}(\mathrm{SD}=1.25$, Me $=5.32)$. Again, there was no significant difference between the sexes: the mean blood glucose in women was $5.66 \mathrm{mmol} / \mathrm{l}(\mathrm{SD}=$ 1.30, $\mathrm{Me}=5.29$ ) and in men $5.72 \mathrm{mmol} / \mathrm{l}$ $(\mathrm{SD}=1.18, \mathrm{Me}=5.47)$ and the difference was within the laboratory error. The relative proportion of individuals with elevated fasting blood glucose levels in the current study was $13.3 \%$ ( $n=13$ ), compared to $86.7 \%$ of people without a deviation in this indicator. Reference values according to the Guidelines and recommendations for laboratory analysis in the diagnosis and treatment of diabetes is $7.0 \mathrm{mmol} / \mathrm{l}(126 \mathrm{mg} / \mathrm{dl})$, fasting blood glucose and $11.1 \mathrm{mmol} / \mathrm{l}(200 \mathrm{mg} / \mathrm{dl})$ after glucose loading or feeding. Blood glucose is an easy-to-measure blood count that is involved in assessing carbohydrate metabolism and diagnosing diabetes, metabolic syndrome, and obesity. People with metabolic disorders are often stratified into high-risk groups for the development of atherosclerotic cardiovascular events. Therefore, the inclusion in the study and measurements of the blood glucose indicator leads to a more complete panel of laboratory indicators and a more adequate assessment of the condition of the subjects.

\section{Relationship between genotype and biochemical markers for assessment of cholesterol profile}

This section discusses the relationships between the genotype and the elements of the cholesterol profile (Cholesterol Total, HDL, LDL, TG) as well as blood sugar profile and blood sugar.

Table 5. Statistical differences in biochemical markers for cholesterol profile and blood glucose between the two genotypes.

\begin{tabular}{|c|c|c|c|c|c|c|}
\hline \multicolumn{2}{|c|}{ Genotype } & Triglycerides & $\begin{array}{c}\text { Cholesterol } \\
\text { total }\end{array}$ & HDL & LDL & $\begin{array}{c}\text { Blood } \\
\text { glucose }\end{array}$ \\
\hline \multirow{3}{*}{ C/T } & Mean & 2.14 & 5.9 & 1.38 & 3.63 & 5.65 \\
\cline { 2 - 7 } & SD & 1.44 & 1.3 & 0.49 & 1.17 & 1.12 \\
\cline { 2 - 7 } & Median & 1.80 & 5.8 & 1.27 & 3.53 & 5.43 \\
\hline \multirow{3}{*}{ T/T } & Mean & 1.70 & 6.0 & 1.51 & 3.69 & 5.72 \\
\cline { 2 - 7 } & SD & 0.86 & 1.2 & 0.47 & 1.12 & 1.38 \\
\cline { 2 - 7 } & Median & 1.58 & 5.8 & 1.48 & 3.73 & 5.25 \\
\hline \multicolumn{2}{|c}{$\begin{array}{c}\text { Sig. } \\
\text { (P-value) }\end{array}$} & 0.170 & 0.855 & $\mathbf{0 . 0 4 4}$ & 0.715 & 0.584 \\
\hline
\end{tabular}

The results of the statistical analyses (Table 5) show statistically significant difference between the two genotypes only in the levels of HDL cholesterol $(P=0.044$, 
at $\mathrm{P}<0.05)$ and in the carriers of the $\mathrm{C} / \mathrm{T}$ genotype lower values of the median are observed $(1.27 \mathrm{mmol} / \mathrm{l})$ of the average concentration of $\mathrm{HDL}$ cholesterol than in the carriers of $\mathrm{T} / \mathrm{T}$ variant - $(1.48 \mathrm{mmol} / \mathrm{l})$. There is no statistically significant difference in the levels of triglycerides, total cholesterol, LDL cholesterol and blood glucose $(P>0.05)$ between carriers of both genotypes.

\section{Nutrigenetic interaction between dietary fatty acid intake, cholesterol profile and genotype}

Blood levels of polyunsaturated fatty acids (PUFAs) are controlled by endogenous synthesis by $\Delta 5$ - and $\Delta 6$ desaturases, encoded by the FADS1 and FADS2 genes and diet, respectively. Whole-genome association studies (GWAS) reported relationships between FADS1FADS2 polymorphisms and variations in plasma concentrations of PUFAs, HDL- and LDL-cholesterol, and triglycerides. However, it is not clear whether dietary intake of PUFAs modulates these associations. Part of the aim of the present study was to assess whether saturated (SFAs), monounsaturated (MUFAs) and polyunsaturated (PUFAs) dietary fatty acids modulate the relationship between the FADS1 rs174547 polymorphism and the lipid profile.

Many candidate genes and GWAS have linked minor alleles of single nucleotide polymorphisms (SNPs) in the FADS1-FADS2 genes to lower concentrations of LC-PUFA in the blood. The minor allele of the nucleotide polymorphism rs 174547 is often associated with higher concentrations of desaturation substrates (such as dietary $L A$ and $A L A$ ) and lower concentrations of desaturation products (such as AA, EPA and DHA) [14-19]. Based on the data from these studies, it was concluded that subjects carrying FADS minor alleles may show lower desaturase activity. In addition, meta-analyses of data from some GWAS have also reported links between FADS cluster SNPs and plasma triglyceride levels and total, HDL- and LDL-cholesterol [20,21].

Although many epidemiological studies have linked dietary intake of PUFAs to cardiovascular risk factors such as plasma lipids and obesity [22-24], few studies have examined the interaction between dietary PUFAs and the variability of the FADS gene cluster on these risk factors [18-20]. Therefore, the aim of the present study was to assess whether and how dietary intake of SFA, MUFA and PUFA altered the relationship between FADS1 rs 174547 polymorphism and metabolic cholesterol markers in the Bulgarian population.

Processed and summarized data from the mean values of biochemical parameters divided by sex and genotype are presented in Table 6.

Table 6. Mean, standard deviation and statistical significance of differences in biochemical plasma parameters by genotype and sex.

\begin{tabular}{|c|c|c|c|c|c|c|c|}
\hline Sex & Genotype & & TG & Chol-total & $\mathrm{HDL}$ & LDL & BG \\
\hline \multirow{6}{*}{$\frac{0}{\frac{\pi}{\pi}}$} & \multirow{3}{*}{$\mathrm{C} / \mathrm{T}$} & $\mathrm{N}$ & 23 & 23 & 23 & 23 & 23 \\
\hline & & Mean & 1.82 & 5.57 & 1.19 & 3.58 & 5.9 \\
\hline & & SD & 1.20 & 1.11 & 0.37 & 1.01 & 1.09 \\
\hline & \multirow{3}{*}{$T / T$} & $\mathrm{~N}$ & 21 & 21 & 21 & 21 & 21 \\
\hline & & Mean & 2.08 & 6.41 & 1.56 & 3.73 & 5.53 \\
\hline & & SD & 0.98 & 1.09 & 0.51 & 1.19 & 1.26 \\
\hline \multicolumn{3}{|c|}{ P value (sig.) } & 0.189 & 0.012 & 0.008 & 0.259 & 0.112 \\
\hline \multirow{6}{*}{ 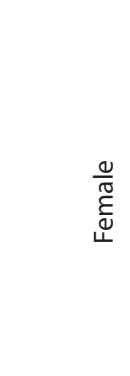 } & \multirow{3}{*}{$\mathrm{C} / \mathrm{T}$} & $\mathrm{N}$ & 37 & 37 & 37 & 37 & 37 \\
\hline & & Mean & 2.34 & 6.18 & 1.50 & 3.66 & 5.49 \\
\hline & & SD & 1.55 & 1.36 & 0.52 & 1.27 & 1.12 \\
\hline & \multirow{3}{*}{$T / T$} & $\mathrm{~N}$ & 39 & 39 & 39 & 39 & 39 \\
\hline & & Mean & 1.49 & 5.76 & 1.48 & 3.67 & 5.82 \\
\hline & & SD & 0.73 & 1.15 & 0.45 & 1.09 & 1.45 \\
\hline \multicolumn{3}{|c|}{$P$ value (sig.) } & 0.007 & 0.121 & 0.950 & 0.975 & 0.678 \\
\hline
\end{tabular}


HDL data in men showed a mean of $1.19 \pm 0.37$ $\mathrm{mmol} / \mathrm{l}$ in participants with the $\mathrm{C} / \mathrm{T}$ genotype and $1.56 \pm 0.51 \mathrm{mmol} / \mathrm{l}$ in those with the $\mathrm{T} / \mathrm{T}$ genotype. For men, values between 0.90-1.45 $\mathrm{mmol} / \mathrm{l}$ carry a moderate risk, above $1.45 \mathrm{mmol} / \mathrm{l}$ are risk-free, and below 0.9 $\mathrm{mmol} / \mathrm{l}$ are at high risk of cardiovascular events.

Summary data for LDL cholesterol show an average of $3.58 \pm 1.01 \mathrm{mmol} / \mathrm{l}$ in male carriers of the $\mathrm{C} / \mathrm{T}$ genotype and $3.73 \pm 1.19 \mathrm{mmol} / \mathrm{l}$ in carriers of the T/T genotype. According to the reference values given by the European Atherosclerosis Community, these values
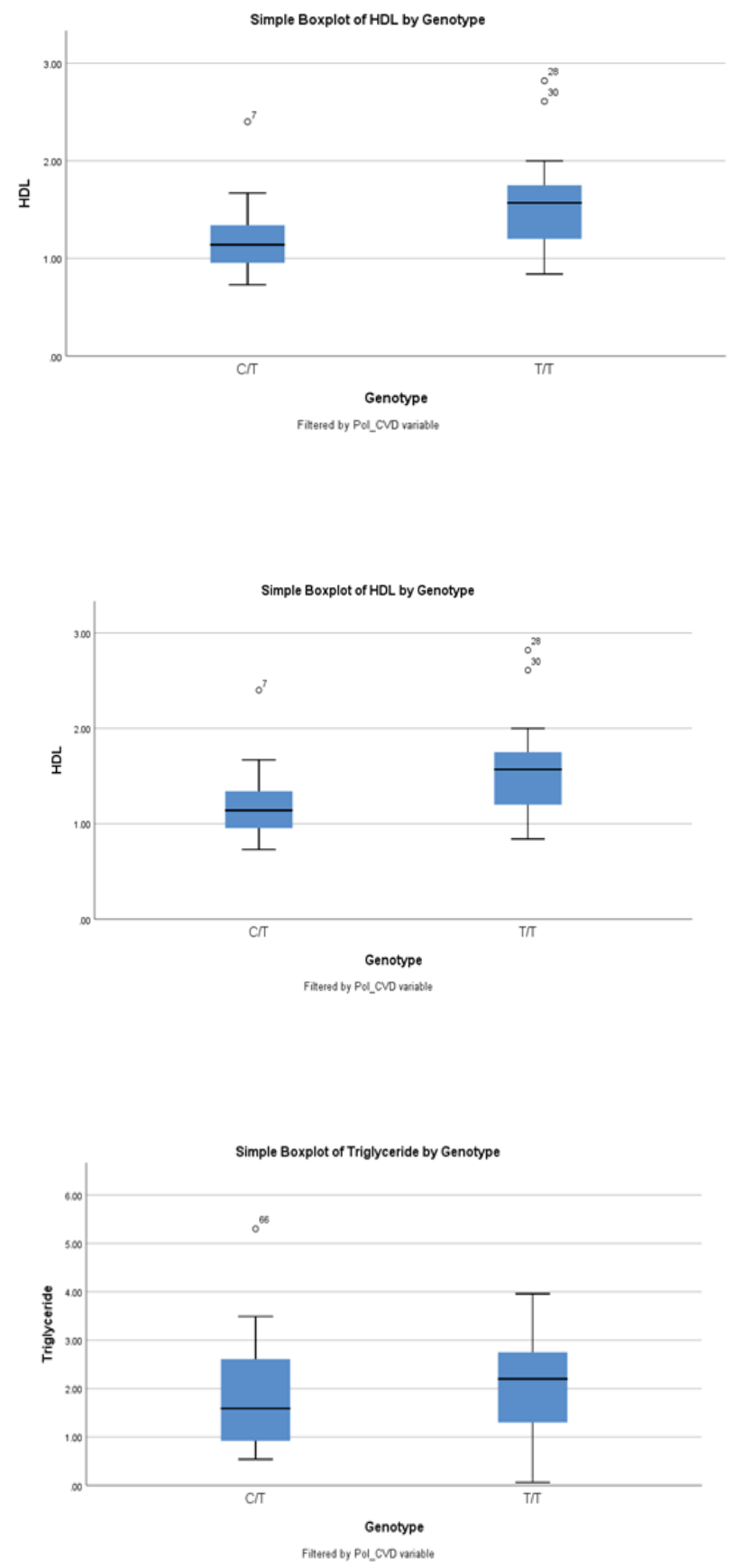

A) Male fall into the extremely high range (from 3.37 to 4.13 $\mathrm{mmol} / \mathrm{l}$ ) and indicate an increased risk of dyslipidaemia and cardiovascular disease.

In women with genotype $\mathrm{C} / \mathrm{T}$ the average value of triglycerides is $2.34 \pm 1.55 \mathrm{mmol} / \mathrm{l}$, and in genotype $\mathrm{T} / \mathrm{T}$ is $1.49 \pm 0.73 \mathrm{mmol} / \mathrm{l}$. Deviation from the reference values $(0.3-1.7 \mathrm{mmol} / \mathrm{l})$ is shown only by the carriers of the $\mathrm{C} / \mathrm{T}$ genotype.

The total cholesterol in the group of women with $\mathrm{C} / \mathrm{T}$ genotype was $6.18 \pm 1.36 \mathrm{mmol} / \mathrm{l}$, and in the group of women with $\mathrm{T} / \mathrm{T}$ genotype $-5.76 \pm 1.15 \mathrm{mmol} / \mathrm{l}$. There is an increase in the mean values in both groups,
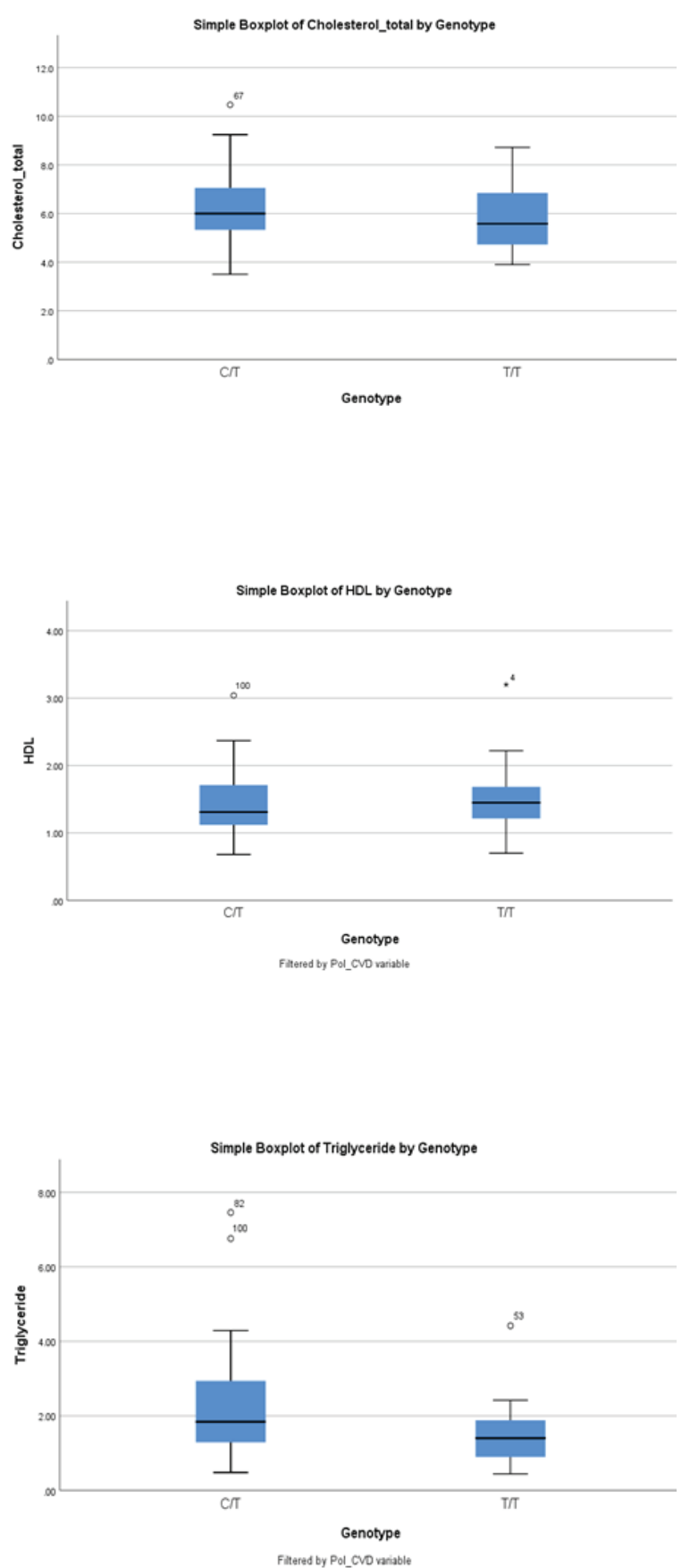

B) Female

Figure 4. Graphical representation of the differences in the average levels of total cholesterol, LDL cholesterol and triglycerides in the different genotypes $(C / T$ and $T / T)$ divided by sex: $A)$ male; $B$ ) female. 
compared to the recommended reference (3.5-5.2 $\mathrm{mmol} / \mathrm{l})$ for this indicator.

The mean value of $\mathrm{HDL}$ cholesterol in the group of volunteers with $\mathrm{C} / \mathrm{T}$ genotype was $1.5 \pm 0.52 \mathrm{mmol} / \mathrm{l}$ and $1.48 \pm 0.45 \mathrm{mmol} / \mathrm{l}$ for carriers of $\mathrm{T} / \mathrm{T}$ genotype. For women, values between $1.15-1.68 \mathrm{mmol} / \mathrm{l}$ carry a moderate risk, above $1.68 \mathrm{mmol} / \mathrm{l}$ are risk-free, and below $1.15 \mathrm{mmol} / \mathrm{l}$ are at high risk of cardiovascular events.

The mean values of LDL cholesterol in volunteers with $\mathrm{C} / \mathrm{T}$ genotype was $3.66 \pm 1.27 \mathrm{mmol} / \mathrm{l}$, and in those with T/T carrier $3.67 \pm 1.09 \mathrm{mmol} / \mathrm{l}$. Compared to the reference values for LDL in women in both groups, this indicator has extremely high values (ref: 3.37-4.13 $\mathrm{mmol} / \mathrm{l}$ ).

To analyze whether there was a statistically significant difference between mean triglyceride (TG) levels, different cholesterol fractions (HDL, LDL, Chol-total), blood sugar in carriers of the two genotypes, a MannWhitney test to compare averages between two independent samples, with abnormally distributed quantitative variables was conducted.

The results of the statistical tests are presented in Table $\mathbf{6}$ and graphically on Figure 4.

From the conducted statistical analysis, it can be noticed that among men there are statistically significant differences in the average levels of total cholesterol $(P$ $=0.012)$ and $\mathrm{HDL}$ cholesterol $(P=0.008)$ between the two genotypes. The difference in mean triglycerides between the two groups was $P=0.189$, and in mean LDL cholesterol was $P=0.259$. Both of the indicators do not meet the criterion of statistical significance. The difference in mean blood glucose values between the two study groups, divided by gender, was also not statistically significant $(P=0.112)$. Among women, there was a statistically significant difference between the two genotypes only in terms of mean triglyceride levels $(P=0.007$, at $P<0.05)$. Differences in total cholesterol $(P=0.121), \mathrm{HDL}$ cholesterol $(P=0.950)$, LDL cholesterol $(P=0.975)$ and blood glucose $(P=0.678)$ did not meet the significance criterion $(P<0.05)$.

Statistical analysis for a significant difference between the average daily intake of different fatty acids (SFA, MUFA and PUFA) in the carriers of the two genotypes ( $C / T$ and $T / T)$ was performed by Mann-Whitney test to compare the mean values between two independent samples, for abnormally distributed quantitative variables. The test results are presented in Table $\mathbf{7}$ and graphically in Figure 5.
Table 7. Mean, standard deviation and statistical significance of differences in mean daily intake of fatty acids, by genotype and sex.

\begin{tabular}{|c|c|c|c|c|c|}
\hline Sex & Genotype & & SFA & MUFA & PUFA \\
\hline \multirow{6}{*}{$\frac{\frac{0}{\pi}}{\frac{\pi}{2}}$} & \multirow{3}{*}{$\mathrm{C} / \mathrm{T}$} & $\mathrm{N}$ & 23 & 23 & 23 \\
\hline & & Mean & 36.91 & 31.51 & 30.00 \\
\hline & & SD & 18.57 & 16.56 & 15.17 \\
\hline & \multirow{3}{*}{$T / T$} & $\mathrm{~N}$ & 21 & 21 & 21 \\
\hline & & Mean & 37.25 & 30.81 & 31.08 \\
\hline & & SD & 19.74 & 14.36 & 16.12 \\
\hline \multicolumn{3}{|c|}{ P value (sig.) } & 0.647 & 0.842 & 0.647 \\
\hline \multirow{6}{*}{$\begin{array}{l}\frac{\mathscr{v}}{\tilde{\sigma}} \\
\frac{\varepsilon}{\Psi}\end{array}$} & \multirow{3}{*}{$\mathrm{C} / \mathrm{T}$} & $\mathrm{N}$ & 37 & 37 & 37 \\
\hline & & Mean & 27.16 & 22.03 & 22.13 \\
\hline & & SD & 13.38 & 9.46 & 10.86 \\
\hline & \multirow{3}{*}{$\mathbf{T} / \mathbf{T}$} & N & 39 & 39 & 39 \\
\hline & & Mean & 26.47 & 24.38 & 24.76 \\
\hline & & SD & 11.06 & 13.30 & 11.59 \\
\hline \multicolumn{3}{|c|}{ P value (sig.) } & 0.059 & 0.054 & 0.111 \\
\hline
\end{tabular}

To study the correlation between laboratory blood counts of cholesterol profile (average triglyceride levels, different cholesterol fractions - HDL, LDL, Choltotal and $B G$ ), the average daily intake of fatty acids

Table 8. The correlation between laboratory blood counts of cholesterol profile, mean daily intake of fatty acids and genotype (C/T and T/T).

\begin{tabular}{|c|c|c|c|c|c|}
\hline \multirow[b]{2}{*}{ Genotype } & \multirow[b]{2}{*}{ Indicator pairs } & \multicolumn{2}{|c|}{ Male } & \multicolumn{2}{|c|}{ Female } \\
\hline & & $\begin{array}{l}\text { Correlation } \\
\text { coefficient }\end{array}$ & Sig. & $\begin{array}{l}\text { Correlation } \\
\text { coefficient }\end{array}$ & Sig. \\
\hline \multirow{4}{*}{$\mathrm{C} / \mathrm{T}$} & $\begin{array}{l}\text { TG:SFA } \\
\text { TG:MUFA } \\
\text { TG:PUFA }\end{array}$ & $\begin{array}{l}0.034 \\
0.167 \\
0.089\end{array}$ & $\begin{array}{l}0.879 \\
0.457 \\
0.693 \\
\end{array}$ & $\begin{array}{l}-0.181 \\
-0.249 \\
-0.180 \\
\end{array}$ & $\begin{array}{l}0.283 \\
0.138 \\
0.285 \\
\end{array}$ \\
\hline & $\begin{array}{l}\text { Chol.Total:SFA } \\
\text { Chol.Total:MUFA } \\
\text { Chol.Total:PUFA }\end{array}$ & $\begin{array}{l}-0.004 \\
-0.042 \\
-0.241\end{array}$ & $\begin{array}{l}0.986 \\
0.851 \\
0.268\end{array}$ & $\begin{array}{l}-0.055 \\
-0.157 \\
-0.169\end{array}$ & $\begin{array}{l}0.748 \\
0.353 \\
0.319\end{array}$ \\
\hline & $\begin{array}{l}\text { HDL:SFA } \\
\text { HDL:MUFA } \\
\text { HDL:PUFA }\end{array}$ & $\begin{array}{l}0.119 \\
0.159 \\
0.146 \\
\end{array}$ & $\begin{array}{l}0.588 \\
0.468 \\
0.507 \\
\end{array}$ & $\begin{array}{r}0.144 \\
0.045 \\
-0.167 \\
\end{array}$ & $\begin{array}{l}0.394 \\
0.790 \\
0.323 \\
\end{array}$ \\
\hline & $\begin{array}{l}\text { LDL:SFA } \\
\text { LDL:MUFA } \\
\text { LDL:PUFA }\end{array}$ & $\begin{array}{l}-0.191 \\
-0.206 \\
-0.242\end{array}$ & $\begin{array}{l}0.383 \\
0.347 \\
0.266\end{array}$ & $\begin{array}{l}-0.175 \\
-0.130 \\
-0.033\end{array}$ & $\begin{array}{l}0.301 \\
0.442 \\
0.848\end{array}$ \\
\hline \multirow{4}{*}{$\mathrm{T} / \mathrm{T}$} & $\begin{array}{l}\text { TG:SFA } \\
\text { TG:MUFA } \\
\text { TG:PUFA }\end{array}$ & $\begin{array}{l}0.182 \\
0.057 \\
0.016\end{array}$ & $\begin{array}{l}0.430 \\
0.806 \\
0.947 \\
\end{array}$ & $\begin{array}{l}0.000 \\
0.060 \\
0.126 \\
\end{array}$ & $\begin{array}{l}0.999 \\
0.715 \\
0.443 \\
\end{array}$ \\
\hline & $\begin{array}{l}\text { Chol.Total:SFA } \\
\text { Chol.Total:MUFA } \\
\text { Chol.Total:PUFA }\end{array}$ & $\begin{array}{r}-0.408 \\
-0.487 \\
-0.213 \\
\end{array}$ & $\begin{array}{r}0.067 \\
\underline{0.025} \\
0.0354 \\
\end{array}$ & $\begin{array}{l}-0.206 \\
-0.065 \\
0.084 \\
\end{array}$ & $\begin{array}{l}0.208 \\
0.692 \\
0.610 \\
\end{array}$ \\
\hline & $\begin{array}{l}\text { HDL:SFA } \\
\text { HDL:MUFA } \\
\text { HDL:PUFA }\end{array}$ & $\begin{array}{l}-0.088 \\
-0.195 \\
-0.395\end{array}$ & $\begin{array}{l}0.703 \\
0.397 \\
0.077\end{array}$ & $\begin{array}{l}-0.052 \\
0.008 \\
0.038\end{array}$ & $\begin{array}{l}0.752 \\
0.961 \\
0.820\end{array}$ \\
\hline & $\begin{array}{l}\text { LDL:SFA } \\
\text { LDL:MUFA } \\
\text { LDL:PUFA }\end{array}$ & $\frac{\frac{-0.618}{-0.677}}{-0.329}$ & $\frac{0.003}{\frac{0.001}{0.146}}$ & $\begin{array}{l}-0.203 \\
-0.115 \\
-0.021\end{array}$ & $\begin{array}{l}0.215 \\
0.485 \\
0.898\end{array}$ \\
\hline
\end{tabular}



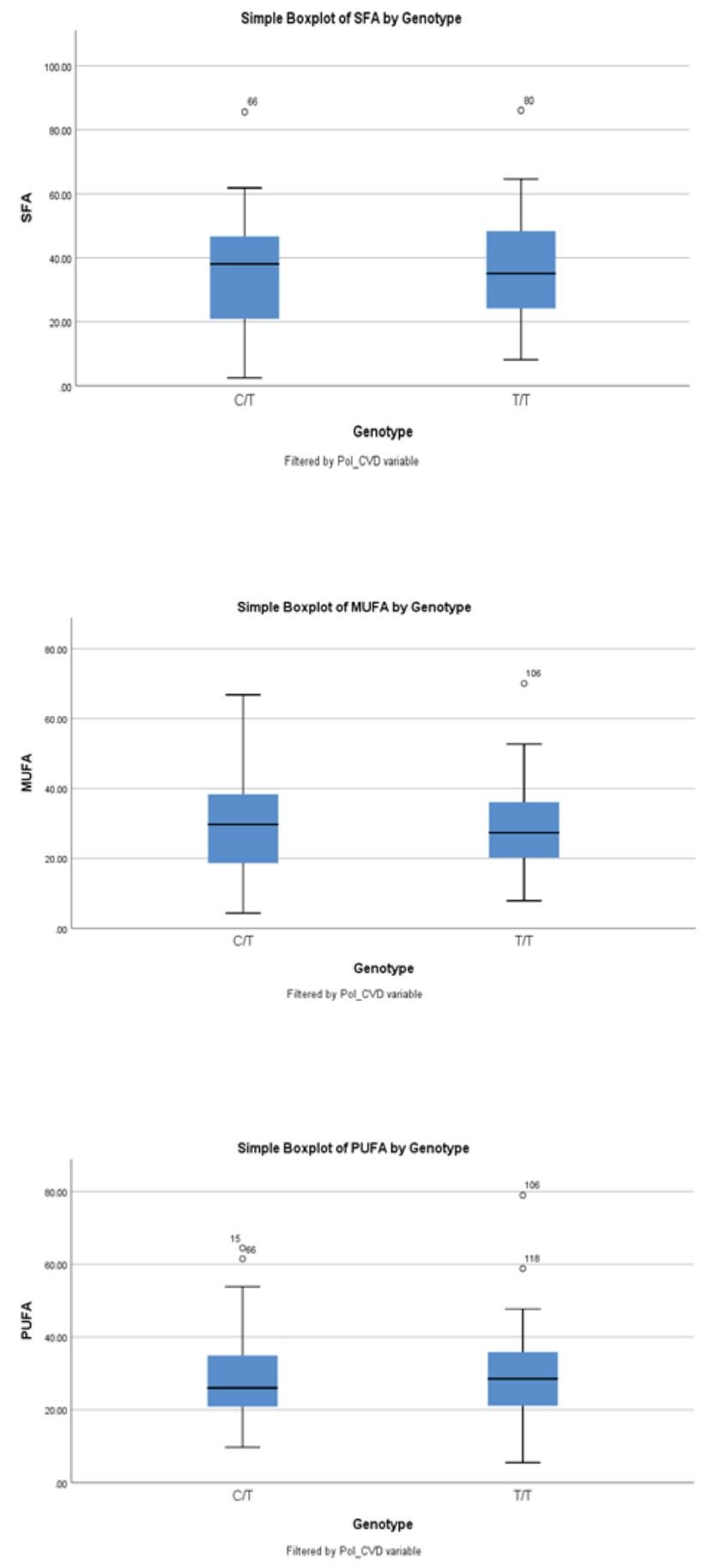

A) Male
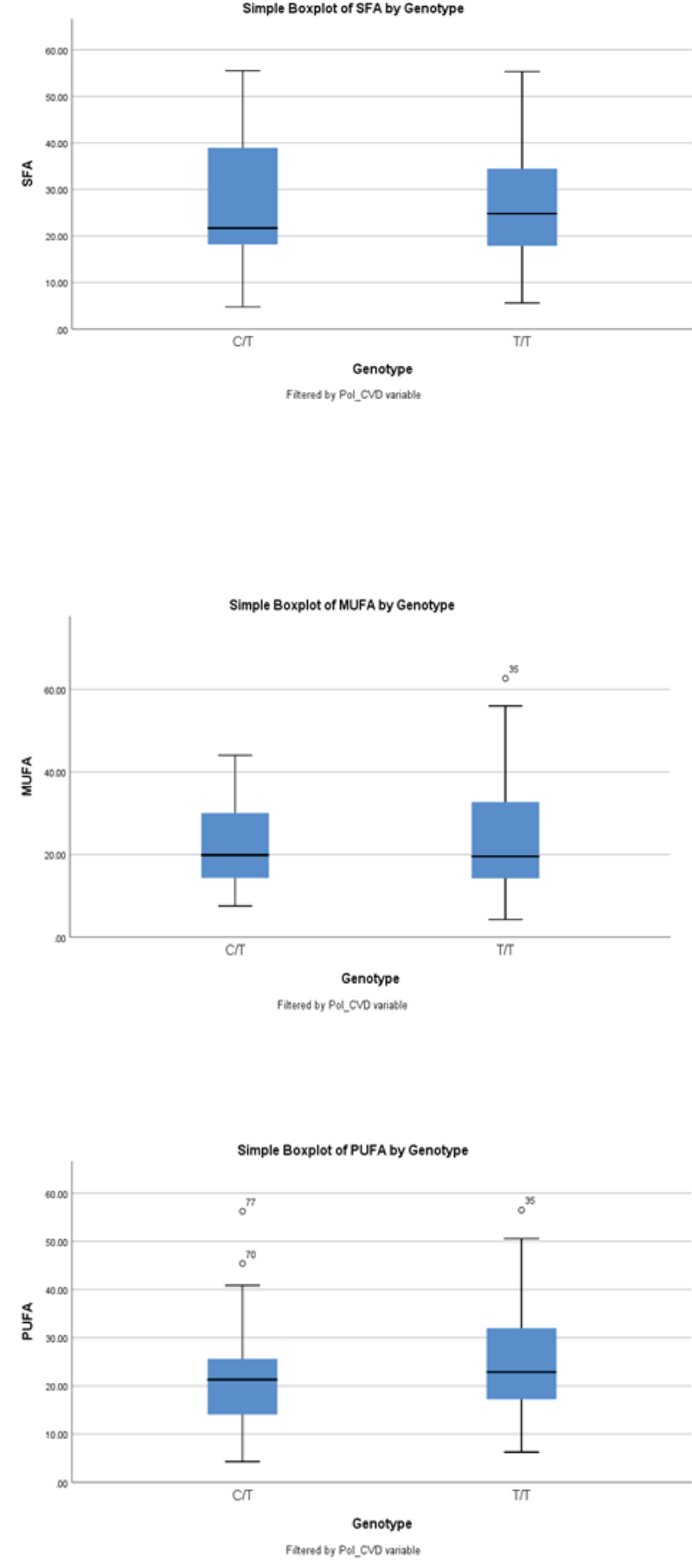

B) Female

Figure 5. Differences in the average daily intake of saturated, monounsaturated and polyunsaturated fatty acids taken with food, in different genotypes and distributed by sex: A) male; B) female.

(SFA, MUFA and PUFA) and the genotype (C/T and T/T) divided by sex, a nonparametric Spearman test was used. Results are presented in Table $\mathbf{8}$ and the following correlations were found, with a confidence level of $\mathrm{p}<0.05$ :

In men with T/T genotype, there is a statistically significant inverse correlation $(r=-0.487, p=0.025)$ between the mean daily intake of MUFA and total plasma cholesterol. No similar correlation was found in women with T/T genotype ( $r=-0.065, r=0.692)$, as well as in men with $C / T$ genotype $(r=-0.042, p=0.851)$. In men with $\mathrm{T} / \mathrm{T}$ genotype, there is a statistically significant negative correlation $(r=-0.618, r=0.003)$ between the average daily intake of SFA and LDL plasma cholesterol. No such significant correlation was found between the average daily intake of SFA and LDL plasma cholesterol in women of the same T/T genotype $(r=-0.203, p$ $=0.215)$. Again, only in men but not in women with $\mathrm{T} / \mathrm{T}$ 
genotype, there was a statistically significant negative correlation ( $r=-0.677, r=0.001)$ between the mean daily intake of MUFA and LDL plasma cholesterol.

The results suggest an effect of the intake of SFA (saturated fatty acids) and MUFA (monounsaturated fatty acids) on the relationship between rs174547 polymorphism and plasma lipids (total and LDL-cholesterol). Such an interaction is observed only in men. In women, such a modification of the relationship between the genotype and the various components of the cholesterol profile was not observed in the present study. This gives reason to believe that this modification is gender-based. The established interactions between the gene variants $C / T$ and $T / T$ and the fatty acids taken with food allow for personalization and optimization of the food model for future health benefits.

\section{CONCLUSION}

In conclusion, personalized nutrition is a rapidly evolving field that involves the use and interpretation of genetic information, and only by acquiring the necessary knowledge can nutritionists accurately translate this nutrigenetic information into clinical practice. All knowledge in the field of nutrigenetics for a given population is a significant contribution to food epidemiology and improving the quality of life. These are the tools for the prevention of chronic non-communicable diseases.

\section{REFERENCES}

1. Simopoulos AP. Genetic variants in the metabolism of omega- 6 and omega- 3 fatty acids: their role in the determination of nutritional requirements and chronic disease risk. Exp Biol Med (Maywood). 2010;235(7):785-95.

2. Cho HP, Nakamura M, Clarke SD. Cloning, expression, and fatty acid regulation of the human delta- 5 desaturase. J Biol Chem. 1999;274(52):37335-9.

3. Cho HP, Nakamura MT, Clarke SD. Cloning, expression, and nutritional regulation of the mammalian Delta- 6 desaturase. J Biol Chem. 1999;274(1):471-7.

4. Simopoulos AP. The importance of the omega-6/omega-3 fatty acid ratio in cardiovascular disease and other chronic diseases. Exp Biol Med (Maywood). 2008;233(6):674-88.

5. Simopoulos AP. Omega-3 fatty acids, the brain and retina. Preface. World Rev Nutr Diet. 2009;99:VII-XII.

6. Mozaffarian D. Fish and n-3 fatty acids for the prevention of fatal coronary heart disease and sudden cardiac death. Am J Clin Nutr. 2008;87(6):1991S-6S.

7. Campos H, Baylin A, Willett WC. a-Linolenic acid and risk of nonfatal acute myocardial infarction. Circulation. 2008;118(4):339-45.

8. Kuzova E, Georgieva T, Duleva V. Development of methodology for analysis of the FADS1 genetic variants: First pilot study in Bulgaria. Hrana i ishrana. 2016;57(1):23-8.

9. Liu F, Li Z, Lv X, Ma J. Dietary n-3 polyunsaturated fatty acid intakes modify the effect of genetic variation in fatty acid desaturase 1 on coronary artery disease. PLoS One. 2015;10(4):e0121255.

10. Mach F, Baigent C, Catapano AL, Koskinas KC, Casula M, Badimon L, et al. 2019 ESC/EAS Guidelines for the management of dyslipidaemias: lipid modification to reduce cardiovascular risk. Eur Heart J. 2020;41(1):111-88.

11. Sacks DB, Bruns DE, Goldstein DE, Maclaren NK, McDonald JM, Parrott M. Guidelines and Recommendations for Laboratory Analysis in the Diagnosis and Management of Diabetes Mellitus. Clin Chem. 2002;48(3):436-72.

12. Collaboration TERF. Lipid-Related Markers and Cardiovascular Disease Prediction. Jama. 2012;307(23):2499-506.

13. Ference BA, Kastelein JJP, Ray KK, Ginsberg HN, Chapman MJ, Packard CJ, et al. Association of Triglyceride-Lowering LPL Variants and LDL-C-Lowering LDLR Variants With Risk of Coronary Heart Disease. Jama. 2019;321(4):364-373.

14. Bokor S, Dumont J, Spinneker A, Gonzalez-Gross M, Nova E, Widhalm K, et al. Single nucleotide polymorphisms in the FADS gene cluster are associated with delta- 5 and delta- 6 desaturase activities estimated by serum fatty acid ratios. J Lipid Res. 2010;51(8):2325-33.

15. Dorajoo R, Sun Y, Han Y, Ke T, Burger A, Chang X, et al. A genome-wide association study of $n-3$ and $n-6$ plasma fatty acids in a Singaporean Chinese population. Genes Nutr. 2015;10(6):53.

16. Guan W, Steffen BT, Lemaitre RN, Wu JHY, Tanaka T, Manichaikul A, et al. Genome-wide association study of plasma N6 polyunsaturated fatty acids within the cohorts for heart and aging research in genomic epidemiology consortium. Circ. Cardiovasc Genet. 2014;7(3):321-31.

17. McCarthy MI, Lemaitre RN, Tanaka T, Tang W, Manichaikul A, Foy M, et al. Genetic loci associated with plasma phospholipid n-3 fatty acids: a meta-analysis of genome-wide association studies from the CHARGE Consortium. PLoS Genet. 2011;7(7):e1002193.

18. Rzehak P, Heinrich J, Klopp N, Schaeffer L, Hoff S, Wolfram $G$, et al. Evidence for an association between genetic variants of the fatty acid desaturase 1 fatty acid desaturase 2 (FADS1 FADS2) gene cluster and the fatty acid composition of erythrocyte membranes. Br J Nutr. 2009;101(1):20-6.

19. Schaeffer L, Gohlke H, Muller M, Heid IM, Palmer LJ, Kompauer I, et al. Common genetic variants of the FADS1 FADS2 gene cluster and their reconstructed haplotypes are associated with the fatty acid composition in phospholipids. Hum Mol Genet. 2006;15(11):1745-56.

20. Consortium GLG. Discovery and refinement of loci associated with lipid levels. Nat Genet. 2013;45(11):1274-83.

21. Teslovich TM, Musunuru K, Smith AV, Edmondson AC, Stylianou IM, Koseki M, et al. Biological, clinical and population relevance of 95 loci for blood lipids. Nature. 2010;466(7307):707-13.

22. Bender N, Portmann M, Heg Z, Hofmann K, Zwahlen M, Egger M. Fish or n3-PUFA intake and body composition: a systematic review and meta-analysis. Obes Rev. 2014;15(8):657-65.

23. Ooi E, Watts G, Ng T, Barrett P. Effect of dietary Fatty acids on human lipoprotein metabolism: a comprehensive update. Nutrients. 2015;7(6):4416-25.

24. Russo GL. Dietary $n-6$ and $n-3$ polyunsaturated fatty acids: from biochemistry to clinical implications in cardiovascular prevention. Biochem Pharmacol. 2009;77(6):93746. 


\title{
FADS1 genetička varijanta rs174547 kao molekularno-genetički biomarker za procenu rizika razvoja kardiovaskularnih bolesti - studija iz Bugarske
}

\author{
Elena Kuzova, Tzveta Georgieva, \\ Vesselka Duleva \\ National Center of Public Health and Analyses, "Acad. Ivan \\ Evst. Geshov", Sofia 1431, Bulgaria
}

\begin{abstract}
Kratak sadržaj
Ispitivanje molekularno-genetičkih biomarkera omogućava pojedinačno proučavanje metaboličkih puteva i glavnih enzima odgovornih za konverziju nutrijenata. Nutrigenetičke informacije dobijene ispitivanjima genskih varijanti i njihovih interakcija sa nutrijentima mogu se koristiti za precizno kreiranje personalizovanih ishrana. Utvrditi značaj FADS1 genetičke varijante rs174547 u metabolizmu
\end{abstract} zasićenih i nezasićenih masnih kiselina koje se unose hranom i identifikovati potencijal rs 174547 kao molekularno-genetičkog markera u panelu nutrigenetičkih studija radi personalizovane ishrane. 123 volontera (43 muškaraca i 80 žena) iz Bugarske, godina od 28 do 65, testirana su za rs 174547 genetičku varijantu FADS1 gena. DNK uzorak uzet je od svakog volontera neinvazivnom metodom (bukalni bris) i genetička varijanta je ispitivana molekularno-genetičkim pristupom kod svake individue. Generalno zdravlje volontera procenjeno je antropometrijom i merenjem procenta masnog tkiva u telu u odnosu na ukupnu masu tela, kao i istraživanjem o njihovom načinu života. Lipidni profil podrazumevao je merenje triglicerida, ukupnog holesterola, HDL i LDL holesterola i šećera u krvi. Informacije o ukupnom unosu hrane prikupljene su putem upitnika. Statističke analize pokazale su da postoje značajne razlike između dva genotipa samo u nivoima HDL holesterola $(P=0.044$, at $P<0.05)$ - nosioci $C / T$ genotipa imaju nižu srednju vrednost koncentracije HDL-a $(1.27 \mathrm{mmol} / \mathrm{l})$ nego nosioci T/T genotipa (1.48 mmol/I). Kod muškaraca se uočavaju statistički značajne razlike u srednjoj vrednosti ukupnog holesterola $(P=0.012)$ i HDL-a $(P=0.008)$ između dva genotipa. Kod žena postoji statistički značajna razlika između dva genotipa samo u srednjoj vrednosti nivoa triglicerida $(P=0.007)$. Razlike u ostalim ispitivanim indikatorima nisu zadovoljile kriterijume za značajnost $(P<0.05)$. Ovi rezultati ukazuju na efekte unosa zasićenih (SFA) i mononezasićenih masnih kiselina (MUFA) na vezu između rs 174547 polimorfizma i lipida u plazmi (totalni i LDL holesterol) samo kod muškaraca. Studija bugarske populacije pokazala je izuzetno nizak unos omega-3 masnih kiselina usled niske konzumacije ribe. Ovi rezultati i nedostatak podataka o genetičkim varijantama FADS1 u Bugarskoj su preduslov za sprovođenje opširnih studija za obe rizične grupe - pacijenti sa kardiovaskularnim bolestima, dislipidemijom ili nedostatkom polinezasićenih masnih kiselina dugog lanca $u$ ishrani i zdravi ljudi.

Ključne reči: genetičke varijante; FADS1 gen; metabolizam masnih kiselina; molekularno-genetički biomarkeri; personalizovana ishrana. 